\title{
CULPABILITY AS AN ESSENTIAL ELEMENT OF INDICTMENT AND THE OPERATIVE PART OF THE JUDGMENT
}

\author{
UDC 343.222:343.8
}

\section{Đorđe Đelić}

\author{
Faculty of Law, University of Niš, Serbia
}

\begin{abstract}
The author deals with culpability as a subjective element of the general notion of a criminal offense, which must be an integral part of every indictment and the operative part (disposition) of the judgment of conviction. First, the article presents the theoretical understanding of the notion of a criminal offense as accepted by the Serbian legislator and the notion of culpability in Serbian criminal law theory and current legislation. Then, the author focuses on the content of indictments filed against the accused person, including the prosecutor's recommendation for imposing criminal sanctions against a juvenile offender, and the content of the judgment on conviction, with specific reference to culpability as an essential element of every indictment and the judgment on conviction. The author further analyzes the issue of the subjective and objective identity of the indictment and judgment in theory and legislation, with focus of culpability and existence or non-existence of a violation of the identity of indictment and judgment in case of entering culpability into the disposition of the judgment on conviction. Finally, the author provides examples from the practice of higher-instance courts in Serbia and a critical standpoint on the legal reasoning in the decisions where the court found a violation of the Criminal Code, given that the scope of an indictment has been exceeded in terms of culpability.
\end{abstract}

Key words: culpability, subjective and objective identity of indictment and judgment, exceeding the scope of indictment

\section{INTRODUCTORY NOTES ON THE NOTION OF CRIMINAL OFFENSE}

In criminal law theory, there are several conceptions on the notion of criminal offense. One of them is the theoretical conception which explains the criminal offense as a combination of objective elements (unlawfulness, explicit prescription in the law) and subjective elements (culpability) (Đorđević, Đorđević, 2014: 33). This conception has been accepted by the Serbian legislator. Thus, Art. 14 (par. 1) of the Criminal Code (CC) ${ }^{1}$ prescribes

Received July $22^{\text {th }} 2020 /$ Accepted September $14^{\text {th }} 2020$

Corresponding author: Đorđe Đelić, PhD student, Faculty of Law, University of Niš, Republic of Serbia.

E-mail: djelicdj1991@gmail.com

${ }^{1}$ Criminal Code (hereinafter: CC), Official Gazette of RS, no.. 85/2005, 88/2005-cor.., 107/2005-cor., 72/2009, $111 / 2009,121 / 2012,104 / 2013,108 / 2014,94 / 2016$ and $35 / 2019$ 
that a criminal offense is an offense prescribed by the law as a criminal offense, which is unlawful and culpable (committed with guilty mind). The elements of the general notion of a criminal offense are the criminal act (actus reus), the explicit prescription of the criminal act by the law, unlawfulness of the act, and culpability. The first three elements are objective elements, while culpability is a subjective element of the general concept of a criminal offense. In addition to the elements that constitute the general concept of a criminal offense, there are also special elements that constitute the essence (corpus delicti) of a specific criminal offense; they are the distinctive elements of specific criminal offenses by means of which they are clearly differentiated. Elements of the general concept of a criminal offense must exist in each criminal offense, whereby the content of the distinctive elements of the specific criminal offense is expressed through them.

\section{THEORETICAL AND NORMATIVE CONCEPTION OF CULPABILITY}

In criminal law theory, the issue of culpability has been discussed from the aspect of substantive and procedural criminal law. In substantive criminal law, culpability is explained as a set of subjective elements that must exist on the part of the perpetrator in order to consider his behavior as a criminal offense (Đorđević, Đorđević, 2014: 43,44). In procedural criminal law, culpability is considered to exist when, in the course of criminal procedure, the defendant is found liable for the commission of a criminal offence that he has been charged with (Jovašević, 2016: 123). Being perceived as a subjective (individual) element of crime, culpability is established for each person who participated in the commission of a criminal offence (Lazarević, 2011: 113).

When it comes to the legal solutions envisaged in the Serbian criminal legislation, Article 22 of the Criminal Code (CC) stipulates that culpability (guilt) exists where the perpetrator was mentally competent at the time of commission of the criminal offense, acting with intent, and aware (or should or could have been aware) that his action is prohibited. Culpability also exists where the perpetrator acted in negligence, if it is explicitly provided by law. From this stipulation, it can be concluded that the concept of culpability entails: 1) mental capacity or sanity, as the reflection of a perpetrator's state of mind at the time of commission of a criminal offense, which entails the ability to understand the significance of his act and manage his actions; 2) intent and negligence, as forms of culpability (guilt), which represent the perpetrator's psychological attitude towards the act as a manifestation of his conduct in the outside world; and 3) awareness that the criminal offence is prohibited by the law, which entails the duty and possibility of being aware of the illicit nature of his act..

The defendant is presumed to be mentally competent at the time of the commission of a criminal offense. Yet, there is no criminal offence if the act is committed in a state of mental incompetence (Article 23 (1) CC. Thus, Article 131 (par. 1) of the Criminal Procedure Code $(\mathrm{CPC})^{2}$ envisages a psychiatric expert examination of the defendant during the criminal procedure in case of any suspicion that the defendant's mental competency was non-existent or diminished at the time of commission of criminal offense; in such a case, the authority in charge of conducting the proceedings will order the defendant's psychiatric examination. Unlike sanity, culpability and awareness of the illicit nature of the act on the

\footnotetext{
${ }^{2}$ Criminal Procedure Code ((hereinafter: CPC), Official Gazette of RS, no. 72/2011, 101/2011, 121/2012, $32 / 2013,45 / 2013,55 / 2014$ and 35/2019
} 
part of the defendant are not presumed, but must be established on the merits of each specific cases and the time of commission of the specific criminal offense.

\section{INDICTMENT AND THE OPERATIVE PART OF THE JUDGMENT ON CONVICTION UNDER THE CRIMINAL PROCEDURE CODE}

Pursuant to the accusatorial principle accepted in the Serbian criminal procedure, domestic courts conduct criminal proceedings on the basis of the indictment of the authorized prosecutor. Article 2 (par. 1, item 10) of the CPC stipulates that criminal charges (accusation) include: an indictment, a motion to indict, a private prosecution, and a motion to pronounce a security measure. Pursuant to Article 332 of the CPC, the indictment must inter alia contain: "a description of the act on which the legal elements of a criminal offence are based, time and place of the commission of the criminal offence, object on which and the means by which the criminal offence was committed, as well as other circumstances needed to determine the criminal offence as precisely as possible". The provision "a description of the act on which the legal elements of a criminal offence are based" makes it clear that it refers not only to the elements of the general concept of a criminal offense, which must be included in every criminal offense, but also to special elements that make up the essence of a particular criminal offense, in the absence of these elements, entering any other facts would be irrelevant, as such description would not constitute a criminal offense.

When it comes to the motion to indict and the private prosecution, Article 500 (par. 1, item 2) of the CPC stipulates that, inter alia, they should contain "a brief description of the act". Undoubtedly, the "brief description of the act" must include the elements that constitute the general concept of the criminal offense as well as the specific elements that make up the essence of that particular criminal offense, so that the indictment is not burdened with unnecessary descriptions that do not constitute elements of the criminal offense. If this wording was to be interpreted as implying the omission of some of the above elements, it would mean that the person is indicted for an act which could not be considered a criminal offense under the provisions of the CC. As noted in theory, "a brief description of the crime" should not be reduced only to a brief description of the criminal offense, but it should also entail a brief description of the essential elements of the crime that the defendant has been charged with (Ilić, Majić, Beljanski, Trešnjev, 2015 : 1130).

When it comes to the motion to impose a security measure of compulsory psychiatric treatment and confinement in a medical institution, or compulsory psychiatric treatment at liberty, the legislator does not describe their content. However, given that these are included in the types of charges and taking into account that the motion is filed when the defendant was insane, the analogous application of the provisions on the indictment, the motion to indict, and the private prosecution may lead to the conclusion that the motion should contain only a description of insanity, but not other elements of culpability, because insanity (mental incapacity) is one of the grounds that exclude the existence of culpability (Article $23 \mathrm{CC}$ ).

If the court finds the defendant guilty, it will render a judgment which must have all the elements referred to in the provision of Article 424 CPC. Inter alia, the judgment on conviction shall state: "the offence of which the defendant is being pronounced guilty, specifying the facts and circumstances which represents the elements of a criminal offence" (Article 424, par.1, item 1 CPC). It is clear that the legislator was referring to the elements of the general concept of a criminal offense and the special elements that constitute the 
essence of a specific criminal offense; otherwise, the court would violate the Criminal Code if it convicted the defendant for a description of criminal offense that does not contain these necessary elements, and if the court itself entered those elements in the operative part of the judgment (holding), it would be a substantive violation of the criminal procedure provisions.

When it comes to criminal proceedings against juveniles, the Act on Juvenile Offenders and Criminal Law Protection of Juveniles ${ }^{3}$ (hereinafter: Juvenile Justice Act) envisages a recommendation for imposing a criminal sanction against the juvenile, which is submitted by the public prosecutor for juvenile offenders. Article 69 (par. 2) of Juvenile Justice Act (JJA) stipulates that the recommendation must, inter alia, contain the legal designation of the criminal offense, which means that it should contain elements of the general notion of the criminal offense and special elements that constitute the essence of that specific criminal offense. When it comes to the court decision, the law stipulates that the decision on imposing an educational measure does not have the operative part (holding) but only designates the specific educational measure imposed by the court; on the other hand, pursuant to Article 78 par. 4 of JJA, the judgment sentencing a juvenile to juvenile imprisonment should comprise the content of a judgment on conviction under the provisions of the CPC.

\section{IDENTITY OF INDICTMENT AND JUDGMENT IN THEORY AND LEGISLATION}

Pursuant to the accepted accusatorial principle, the subject matter of indictment are the accused person and the criminal offense for which he is accused (Grubač, 2014: 144). The subject matter of the indictment determines the subject matter of the judgment; their contents must match in terms of the person(s) identified as the accused (subjective identity in the indictment) and in terms of the facts contained in the indictment and the judgment (objective identity) (Knežević, 1999: 172).

When it comes to the subjective identity, the theory agrees that the judgment must refer to the person accused of committing the criminal offence. Changes in the form of culpability (intent, negligence) and contribution to the commission of a crime (perpetrator, accomplice in the narrow sense) do not affect the change of subjective identity (Ilić, 2015: 268). This provision is also envisaged in Article 420 (par. 1) of the CPC, which stipulates that the judgment can only apply to the person being accused. If it is established during the criminal proceedings that the crime was committed by another person, the court would have to acquit the defendant. The authorized prosecutor could not extend the indictment to that other person because it would constitute a violation of identity; instead, he would have to raise a new indictment against that person.

The question of objective identity of an indictment and a judgment has been a matter of considerable interest in both theory and practice, but there is no unique stance on this issue. The objective identity of an indictment and judgment has a formal and a material aspect. The formal aspect of objective identity means that the indictment and judgment must correspond in terms of legal qualification, while the material aspect of objective identity implies the matching factual description of the indictment and the judgment (Knežević, 1999: 170).

The criminal procedure theory agrees that the court is not bound by the formal aspect of the identity of the indictment and the judgment (Knežević, 1999: 173). Thus, even when

\footnotetext{
${ }^{3}$ Act on Juvenile Offenders and Criminal Law Protection of Juveniles (hereinafter: Juvenile Justice Act),, Official Gazette of RS, no. 85/2005
} 
the court finds that the established factual situation does not correspond to the legal qualification from the indictment, it will not acquit the defendant of the accusation, but will qualify the established factual situation according to its legal assessment and find the defendant guilty of the committed criminal offense. This stance has been accepted by the legislation, which provides in Article 420 (par. 2) of the CPC that the court is not bound by the prosecutor's recommendation regarding the legal qualification of the criminal offense.

In theory and judicial practice, there is no unique stance on the material aspect of the objective identity of the indictment and the judgment, particularly concerning the degree of link between the indictment and the judgment. Article 420 (par. 1) of the CPC prescribes that the judgment may refer to the act which is the subject matter of the accusation contained in the filed indictment, or in the indictment which is amended or expanded in the main trial hearing. It is disputable to what extent the court is bound by the legal designation of the criminal offense as contained in the indictment, and whether it could intervene in the disposition of the judgment in case a different factual situation is established in the trial hearing than the one specified in the indictment and if the authorized prosecutor does not change the indictment or file a new one based on Article 409 of the CPC, without violating the material aspect of the identity of the indictment and the judgment. The question of the material aspect of the objective identity of the indictment and the judgment is of special importance for exercising the right to defence; in order to prepare the defense, the defendant must know in advance what factual situation he is charged with.

There are several theories on the material aspect of the objective identity of the indictment and the judgment. According to the older theory, the identity of the indictment and the judgment exists if the judgment refers to an event from the indictment, and the judgment is to be based on the facts established at the main trial hearing (Brkić, 2004). The court could establish a different factual situation from the one contained in the indictment, without violating the identity of the indictment and the judgment, provided that it still refers to the same event. This conception is based on the principle of material truth; thus, by applying this theory in practice, the court would be bound only by that specific past event. For example, the defendant may be convicted of criminal offenses which are part of the specific past event but which are not the subject matter of the charges (e.g. in case of a continuing criminal offense or for a completed criminal offense, although the subject of the indictment is an attempted criminal offense) (Brkić, 2004). Changes in the factual situation could be both beneficial and detrimental to the defendant (Ilić, 2015: 270, 271).

According to more recent theory, when issuing the judgment, the court is bound by the factual description given in the indictment, but the link to the factual description is not an absolute one (Bajović, 2013: 201). Yet, there is no unique stance in the more recent theory on the extent to which changes in the factual description are possible without violating the identity of the indictment and the judgment. Here, we can point to the theory of "a modified" and "another" act, and the theory of factual sets. According to the theory of a "modified" and "another" (substantially different) criminal offence, the identity of the indictment and the judgment is considered to exist if the court convicts the defendant for a modified criminal offence, and not for another criminal offense. A modified criminal offense exists if the act is basically the same, but some non-essential elements of the corpus delicti of the criminal offense (e.g. place, time, manner of execution) have been modified or concretized. It would be a modified act even if the judgment referred to another (more or less aggravated) form of the same criminal offense which is the subject matter of the indictment (e.g. serious bodily harm and light bodily injury, aggravated murder and murder). Based on the results 
of the main trial hearing, the court may change and supplement the factual description of the act as long as it remains within the limits of the legal qualification that corresponds to the factual description contained in the indictment (Grubiša, 1960: 601-618). For instance, if the court establishes that the defendant has acquired a greater amount of unlawful material gain than the amount he was charged with, the court may convict the defendant of having obtained a greater unlawful material gain if it does not affect the legal qualification of such a factual situation. On the other hand, it is considered in theory that there is a violation of the identity of the indictment and the judgment if the court convicts the defendant for another act. Another act exists if it is substantially different from the act that is the subject matter of the accusation, regardless of whether it has less or more serious consequences for the accused (e.g. assistance to the perpetrator after the commission of the criminal offense and unauthorized possession of narcotics (Ilić, 2015: 271).

The theory of factual sets is another theory related to the material aspect of the objective identity of the indictment and the judgment. According to this theory, the factual description in the indictment is a set which includes several subsets; thus, there is a subset consisting of important features of the criminal offense, a subset consisting of qualifying and privileged circumstances, and a subset consisting of other optional elements of the criminal offense (e.g. place and time, means of committing the crime, etc.). The court is not absolutely bound by the factual description of the indictment. The court could omit from the factual set the elements that have not been proven and convict the defendant for the factual set without those elements if they are legally qualified as a criminal offense. In terms of culpability, it is possible to grade it from higher to lower degrees; thus, sanity can be modified into reduced sanity and direct intent may be changed into probable intent, provided that no modifications are made from probable intent into conscious negligence, as they are not part of the set-subset relationship. Changes are also possible in terms of consequences; thus, the defendant can be convicted for a consequence of a lesser degree than the one described in the indictment; qualifying circumstances may be reduced in quantity but new ones cannot be added, nor may the existing ones be replaced with new ones because they are not part of the set-subset relationship; privileged circumstances may be added even though they are not described in the indictment, and changes in terms of time, place, means of execution (etc.) are also possible (Majić, 2011: 85-105).

When it comes to the identity of the indictment and the judgment in the procedure against juveniles, Article 74 (par. 4) of the Juvenile Justice Act (JJA) stipulates that the court, even without the recommendation of the public prosecutor, renders a decision on the basis of the factual situation established in the main trial hearing. Considering that the judgment is rendered when the juvenile is found guilty and sentenced to juvenile imprisonment, and given that the court is not bound by the factual description from the prosecutor's recommendation for imposing a criminal sanction, we believe that this provision must be interpreted so that the court itself must not introduce elements of culpability, nor other essential features of the criminal offense; the law clearly prescribes that the recommendation for imposing a criminal sanction must contain a description of the criminal offense, which would enable the court to establish a different factual situation from the one contained in the recommendation. Thus, the court is not authorized to enter essential elements of the criminal offense, but the court can modify them if it is indicated by the factual situation.

We can conclude that the theory of a modified and another act and the theory of factual sets can be applied to the normative solution pertaining to adults, since the older theory speaks in favor of the connection to the specific event and not to the factual situation from 
the indictment. Here, we will not deal with the arguments for and against these theories because the question of the identity of the indictment and the judgment is not the main topic of this paper. As this paper explores the issue of the court's self-initiated inclusion of elements of culpability in the disposition of the judgment on conviction, we can conclude that both the theory of a modified and another act and the theory of factual sets agree that the essential elements of a criminal offense cannot be entered in judgment by the court, as this would lead to expanding of the scope of the indictment.

\section{CULPABILITY AS AN ELEMENT OF INDICTMENT AND JUDGMENT IN JUDICIAL PRACTICE (CASE LAW)}

As formerly noted, culpability is an essential element of every criminal offense. Thus, a description of the elements of culpability must be an integral part of every indictment (except in the previously explained cases) and every judgment on conviction (except the decision imposing the security measure of compulsory psychiatric treatment and confinement in a medical institution, or compulsory psychiatric treatment at liberty when the perpetrator was insane at the time of the commission of the illegal act). The court is bound by the indictment of the authorized prosecutor, and it cannot enter the elements that were not included in the indictment into the disposition of the judgment. It refers to the elements that constitute the general notion of a criminal offense and the special elements that constitute the substance (corpus delicti) of a specific criminal offense.

In recent years, judicial practice has recorded cases where courts undoubtedly violated the Criminal Code, either by finding defendants guilty of actions that do not contain all elements of a criminal offence or by exceeding the scope of indictment (by entering into the judgment the elements of culpability which were not included in the factual description of the indictment. At this point, the author presents some of these decisions and comments on them.

Case 1: Based on the judgment of the Basic Court in Despotovac, Court Unit in Svilajnac K 792/12 of 25 October 2017, which was confirmed by the judgment of the Higher Court in Jagodina Kž1 37/18 of 23 February 2018, the defendant was found guilty of the criminal offense of fraud under Article 208 (par. 1) CC and convicted. In response to the aforementioned judgments, the defense counsel of the defendant filed a request for the protection of legality, in which he referred to a substantial violation of the criminal procedure provisions contained in Article 438 (par. 1, item 9) of the CPC, alleging that the court entered the words "capable of understanding the significance of its act and managing its actions" in the disposition of the final judgment. The Supreme Court of Cassation, in its judgment Kzz 637/2018 of 05 June 2018 , refused the filed request against the final judgments and stated in the reasoning that "an objective identity between the indictment and the judgment exists if the judgment is based not only on an identical event from the past, but it must not exceed the factual description of the event as contained in the indictment, particularly in terms of the act of commission of the act. Otherwise, the court violates the statutory requirement of objective identity between the indictment and the judgment. Thus, by entering the words "capable of understanding the significance of its act and managing its actions" into the final judgment, the first instance court did not exceed the scope of the indictment as the disposition of the final judgment remained within the factual basis of the indictment."

We cannot agree with this reasoning of the court because the court is bound by the factual description of the indictment not only in part concerning the act of commission of 
the criminal offense but also in terms of other essential features of the criminal offense. Sanity (as an element of culpability) cannot be introduced in the disposition of the final judgment on the initiative of the court, which is clearly specified both in the theory of a modified and another act and in the theory of factual sets. In this case, the court unequivocally exceeded the scope of the indictment as there was a violation of the identity of the indictment and the judgment.

Case 2: Based on the judgment of the Supreme Court of Cassation Kzz. 284/19 of 21 March 2019, the request for the protection of legality, submitted by the defense counsel of the defendant against the final judgment of the Basic Court in Pančevo, was rejected. The request stated that there was a substantial violation of the criminal procedure provisions contained in Article 438 (par. 1 item 9) of the CPC, as the court entered in the disposition of the judgment that the defendant had committed the criminal offense "in a state of sanity", which is the fact that the Basic Public Prosecutor's Office in Pančevo did not state in the indictment. In its judgment, the Supreme Court reasoned that "the first instance court in the judgment only adjusted the disposition of the judgment to the established factual situation. Thus, by entering the wording that the defendant acted "in a state of sanity" into the disposition of the judgment, the court did not exceed the scope of the indictment, given that the defendant's ability to understand the significance of his act and manage his actions, as a rebuttable presumption, was not called into question during the proceedings."

We cannot accept the conclusion that, given the fact that sanity was not contested, entering sanity in the disposition of the judgment did not violate the identity of the indictment and the judgment. As an essential element for establishing culpability, sanity had to be included in the indictment, which was not done in the concrete case. Considering that the issue involves an element of culpability as an essential feature of a criminal offense, the court should not have intervened in that part by entering sanity in the disposition of the judgment, which is a common stance in the theory of a modified and an other act, and in the theory of factual sets. Thus, the identity of the indictment and the judgment was violated in this case. Consequently, the court should have acquitted the defendant of the accusation since the act cannot be considered a criminal offense, due to the lack of sanity as an element of culpability.

Case 3: Based on the judgment of the Basic Court in Pirot 1K.br.108/18 of 27 September 2018, which was confirmed by the judgment of the Higher Court in Pirot Kž1.br. 137/18 of 3 April 2019, the defendant was found guilty of the criminal offense of insult under Article 170 (par. 1) CC and convicted. In the request for the protection of legality, the defense counsel for the defendant referred to the fact that the final judgments contained a substantial violation of the criminal procedure provisions envisaged in Article 438 (par. 1, item 9) of the CPC, alleging that the first instance court exceeded the scope of the indictment by entering "sanity" and "awareness of illegality" in the disposition of the judgment, which were not stated in the private criminal complaint. The Supreme Court of Cassation, in the reasoning of the judgment Kzz 844/2019 of September 12 2019, stated that these allegations were unfounded since the scope of indictment cannot be exceeded by adding "in a state of sanity" in the disposition of the judgment, given that sanity is implied in the course of criminal proceedings and that it was not contested. The Court also stated that the lower courts did not exceed the scope of the indictment, and that the final judgments refer to the act for which the defendant was accused (i.e. the criminal offense of insult under Art. 170 par. 1 of the $\mathrm{CC}$ ); thus, given the fact that the said criminal offense can be committed only with intent, the subjective features of this criminal offense in this case derive from objective facts described as the defendant's actions 
in a private criminal complaint. Therefore, the court specified these features but the factual description in the judgment remained within the limits of the factual grounds stipulated in the private criminal complaint. The Court also noted that the attorney-at-law of the private prosecutor specified the private criminal complaint at the main trial hearing by adding the words "with intent to disparage", which implies that the defendant was aware of the illegality of the act and there was intent on his part.

We do not agree with this reasoning of the Supreme Court of Cassation because sanity and awareness of the illicit nature of the crime are elements of culpability as a general feature of a criminal offense. As previously noted, the factual part of the indictment must contain all general features and special elements of the criminal offense the defendant is charged with. In this case, the description of culpability (in the private criminal complaint) did not contain the wording on sanity and awareness of the prohibition of the act. From the reasoning of the judgment, it may be concluded that there was no change in this part of the private criminal complaint during the main trial hearing. Although sanity is presumed in the course of criminal proceedings, we cannot accept the position that it was not necessary to enter it in a private criminal complaint merely because it was not disputed, nor can we accept the position that its inclusion into the judgment does not constitute exceeding the scope of the indictment. As an important feature of the criminal offense, sanity must be described in the indictment, and the court cannot enter it in the judgment because it thereby exceeds the scope of the indictment, which is something that both the theory of a modified and another act and the theory of factual sets agree on. Although the subjective elements of the criminal offense are determined on the basis of objective circumstances contained in the facts, the same elements must be described in the indictment, which the court is bound by. As the private prosecutor did not do so, the court itself could not enter the element concerning the awareness of the illicit nature of the crime because it implies that the court added elements that constitute a criminal offense to the behavior described in the private criminal complaint, which obviously entails exceeding of the scope of the indictment.

Case 4: Based on the judgment of the Higher Court in Požarevac 2K.br. 1/19 of 24 April 2019, the defendants A.A. and B.B. were found guilty of committing the criminal offense of robbery in complicity under Article 206 (par. 1) in conjunction with Article 33 of the CC, notably "... in a state of sanity, aware of the prohibition of their act, by prior agreement ... with the intention to obtain illegal material gain for themselves and others". Based on the judgment of the Court of Appeals in Kragujevac Kž1 557/19 of 05 September 2019, the appeal of the defendants' defense counsel was partially upheld and the judgment of the Higher Court in Požarevac 2K 1/19 of April 242019 was overturned in the part concerning the legal assessment of the act and the decision on the criminal sanction. In the request for the protection of legality filed with the Supreme Court of Cassation, the defense counsel of defendant AA stated that there was a violation of Article 439 (item 1) of the CPC, considering that the actions for which the defendant was found guilty are not a criminal offense, and given the fact that the disposition of the judgment of the first instance court does not specify that the defendant committed the criminal offense with intent. The Supreme Court of Cassation, in its judgment Kzz no. 154/20 of 19 February 2020, rejected the request as unfounded, explaining that it was true that the disposition of the judgment did not explicitly state that defendant AA acted with direct intent, but that "the actions described in the disposition of the judgment of the first instance court as well as alleging that the defendant in the state of sanity was aware of the illegality of his act, undoubtedly signify the defendant's awareness of illicit nature of his act and that the crime was committed with intent". 
We cannot agree with this reasoning of the Supreme Court of Cassation. Intent is one of the three constitutive elements of culpability, but each element of culpability is separate and independent; each of these elements must be clearly stated in the indictment of the authorized prosecutor and determined by the court as such. The legal designation of sanity, one's awareness of the illegal nature of the act, and the intent to obtain illegal material gain for oneself and others cannot compensate for he lack of legal designation of direct intent in the disposition of the judgment, because direct intent as a form of culpability is not contained in these elements. Such description in the disposition of the judgment clearly indicates that this factual description cannot represent the essence of any criminal offense, due to the omission of culpability as a psychological attitude of the perpetrator towards his act. Legislation explicitly envisages the elements that must be included in the indictment, motion to indict, and private criminal complaint. One of the important elements is culpability, which encompasses sanity, intent or negligence, and awareness of the illicit nature of the act. Article 14 of the CC clearly defines what constitutes a criminal offense. In this case, the factual description in the disposition of the judgment does not have all the elements that constitute the general notion of a criminal offense; for that reason, this factual description does not constitute a criminal offense.

\section{CONCLUSION}

In domestic criminal legislation, according to the accepted conception of a criminal offense as a combination of the objective and objective elements, culpability is an essential feature of a criminal offense. The indictment, by which the authorized prosecutor determines the subject matter of the trial, must contain a description of the criminal offense that the defendant is charged with, including both the elements of the general notion of the criminal offense and the special (distinctive) elements that constitute the essence of a specific criminal offense. The Serbian Criminal Procedure Code prescribes that the disposition of the final judgment on conviction shall inter alia include a legal designation of the criminal offense. It clearly implies that culpability must be described as a subjective element of the general notion of a criminal offense. The court must not include these subjective elements in the disposition of the final judgment, unless they are specified in the indictment. If it occurs, there is a violation of the defendant's right to defense. Having in mind the accepted accusatorial principle in criminal procedure, it also entails the intertwining of the procedural functions. If the court has convicted the defendant for a factual description that lacks either an element of the general notion of a criminal offense or an element that constitutes the essence of a specific criminal offense, it would also constitute a violation of the Criminal Code. If the court itself included these elements in the disposition of the final judgment, it would also constitute a substantial violation of the identity of the indictment and the judgment.

\section{REFERENCES}

Bajović, V., (2013). Objektivni identitet presude i optužbe (Objective Identity of a Judgment and Indictment), Anali Pravnog fakulteta u Beogradu, vol. 61, br. 1, 2013, str. 198-222

Brkić, B., (2004). Identitet između presude i optužbe (The identity of a judgment and indictment), Hrvatska pravna revija, broj 4/2004, Zagreb, Hrvatska; available at http://www.vsrh.hr/CustomPages/Static/HRV/ Files/BrkicB_Identitet-izmedju-presude-optuzbe_2004.pdf, (accessed 05.07.2020)

Đorđević, M., Đorđević, Đ., (2014). Krivično pravo (Criminal Law), Projuris, Beograd 
Grubač, M., (2014). Krivično procesno pravo (Criminal Procedure Law), Projuris, Beograd

Grubiša, M., (1960). Pravila za praktično rešavanje pitanja objektivnog identiteta presude i optužbe (Rules for resolving the issue of the objective identity of a judgment and indictment), Naša zakonitost, br. 11-12, 1960, str. 601-618

Ilić, G., Majić, M., Beljanski, S., Trešnjev, A., (2015). Komentar Zakonika o krivičnom postupku (Commentary on the Criminal Procedure Code), JP Službeni glasnik, Beograd

Ilić, I., (2015). Identitet presude i optužbe (Identity of a judgment and indictment), Zbornik radova Pravnog fakulteta $u$ Nišu, br. 69, 2015, str. 267-282

Jovašević, D., (2016). Krivično pravo, opšti deo (Criminal Law, General part), Dosije, Beograd

Knežević, S., (1999). Vezanost presude optužbom (Link between the judgment to the indictment), Zbornik radova Pravnog fakulteta u Nišu, br. 38-39, 1999, str. 170-179

Lazarević, Lj., (2011). Komentar Krivičnog zakonika (Commentary on the Criminal Code), Pravni fakultet Univerziteta Union, Beograd

Majić, M., (2011). Činjenični identitet presude i optužbe: preispitivanje granica dozvoljenog odstupanja (The Factual Identity of a Judgment and Indictment: reassessing the limits of permitted divergence), Bilten Vrhovnog kasacionog suda, br. 2, 2011, str. 85-105

\section{Legal documents}

Krivični zakonik (Criminal Code of the Republic of Serbia), Službeni glasnik RS, br. 85/2005, 88/2005-ispr., 107/2005-ispr., 72/2009, 111/2009, 121/2012, 104/2013, 108/2014, 94/2016 i 35/2019

Zakonik o krivičnom postupku (The Criminal Procedure Code), Službeni glasnik Republike Srbije, br. 72/2011, 101/2011, 121/2012, 32/2013, 45/2013, 55/2014 i 35/2019

Zakon o maloletnim učiniocima krivičnih dela i krivičnopravnoj zaštiti maloletnih lica (Act on Juvenile Offenders and Criminal Law Protection of Juveniles), Službeni glasnik Republike Srbije, br. 85/2005

\section{Judicial practice}

Пресуда Врховног касационог суда (Judgment of the Supreme Court of Cassation) Кзз. 637/18 од 05. 06. 2018 Пресуда Врховног касационог суда (Judgment of the Supreme Court of Cassation) Кз3. 284/19 од 21.03.2019. Пресуда Врховног касационог суда (Judgment of the Supreme Court of Cassation) Кз3 844/19 од 12.09.2019. Пресуда Врховног касационог суда (Judgment of the Supreme Court of Cassation) Кзз 154/20 од 19.02.2020.

\section{KRIVICA KAO BITNO OBELEŽJE OPTUŽBE I IZREKE PRESUDE}

Autor se u radu bavi krivicom - subjektivnim elementom opšteg pojma krivičnog dela, koja mora biti sastavni deo svakog optužnog akta i izreke presude. Najpre se izlaže objektivno - subjektivno shvatanje pojma krivičnog dela prihvaćeno od strane domaćeg zakonodavca i pojam krivice u teoriji i normativi, zatim sadržaj optužnih akata koji se podnose protiv okrivljenog lica, odnosno predloga za izricanje krivičnih sankcija prema maloletnom licu i sadržaj izreke osuđujuće presude, sa aspektom na krivicu, kao neophodnim elementom svakog optužnog akta odnosno izreke osuđujuće presude. Autor dalje razmatra pitanje identiteta presude i optužbe u teoriji i normativi, sa pažnjom na krivicu i postojanje ili nepostojanje povrede identiteta presude i optužbe u slučaju unošenja krivice od strane suda u izreku presude. Na kraju, autor izlaže primere iz prakse višestepenih sudova dajući kritički stav u pogledu obrazloženja oduka ovih sudova vezano za postojanje povrede krivičnog zakona, odnosno prekoračenja optužbe a u vezi sa pitanjem krivice.

Ključne reči: krivica, identitet presude i optužbe, prekoračenje optužbe 